\title{
Effect of Applied Sulphur on Elemental Sulphur Contents in Maize
}

\author{
Ansa Rebi ${ }^{1 *}$, Komal javed ${ }^{2}$, Sehrish Kiran $^{2}$, Salman $^{1}$, Samiya Ghazafar, Hina Ruby ${ }^{3}$ \\ ${ }^{1}$ Institute of Soil and Environmental Sciences, University of Agriculture -38040, Faisalabad, Pakistan \\ ${ }^{2}$ National Institute of Food Science and Technology, University of Agriculture -38040, Faisalabad, Pakistan \\ ${ }^{3}$ Department of Agronomy, University of Agriculture -38040, Faisalabad, Pakistan
}

How to cite this paper: Rebi, A., javed, K., Kiran, S., Salman, Ghazafar, S., Ruby H. (2020) Effect of Applied Sulphur on Elemental Sulphur Contents in Maize. International Journal of Food Science and Agriculture, 4(1), $1-5$.

DOI: $10.26855 /$ ijfsa.2020.03.001

*Corresponding author: Ansa Rebi, Institute of Soil and Environmental Sciences, University of Agriculture -38040, Faisalabad, Pakistan.

Email: 2013ag3549@uaf.edu.pk

\begin{abstract}
Maize is the rival of the cereals crops which positions in the third followed by wheat and rice in the whole world. Its creation potential is high so it with fertilization. Demand of cereals crops are increasing due to increasing population of developing countries. Sulphur is a macro nutrient just under the importance of nitrogen $(\mathrm{N})$, phosphorous $(\mathrm{P})$ and potassium $(\mathrm{K})$. When Sulphur deficiency accrues the efficiency of other applied nutrients are affected. The experiment was conducted in Auyob agriculture research institute in Faisalabad. There stood 5 treatments along with 3 replications. There were five levels of sulphur was applied @ 0, 10, 20,30, and 40 $\mathrm{kgha}^{-1}$. with the recommended dose of NPK. Elemental S (Dusting Sulphur) in powdered form was used as fungicides against powdery mildews, apple scab and black spot. The result was statistically analysed by using the standard RCBD design. The result was showed that after applying Sulphur fertilizer $\mathrm{pH}$ of soil decreased. This in turn facilitates the solubility of heavy metals and grain number ear. Fresh weight, dry weight, grains yield, was increased with the increasing level of sulphur. The application of S at rate of $40 \mathrm{~kg} / \mathrm{ha}$ then 0.99 $\mathrm{tha}^{-1}$ average particle profit of maize was increased. It was concluded that the concentration of S increased with the increase of S fertilizer application.
\end{abstract}

\section{Keywords}

Sulphur, Maize

\section{Introduction}

Maize is a well-known cereal crop of the world, sometimes referred to as the king of grain crops. It stands $3^{\text {rd }}$ in importance after wheat and rice. Almost 1.02 million .Hectares are cultivated with maize each year. This production is $6.4 \%$ of the overall grain yield in the country, having 3.49 tones/hectare average grain yield and 3.56 million tons annual yield of the crop (GoP, 2008). The crop is either grown in spring or autumn seasons due to its resistance to a variety of climatic conditions. In the lowland localities of irrigated Punjab, maize is preferably grown in the spring season. The maize genotypes have a comparatively low production potential as compared to other genotypes of the crop (Anonymous, 2008). In Pakistan, about 1117 thousand hectare area is under maize cultivation. It contributes $2.1 \%$ contribution to the value added in agriculture. Moreover, it contributes a $0.4 \%$ share in GDP (GoP, 2013-14).

There is a dramatic increase in the population in Pakistan, as compared to the average increase in world's population i.e., $1.8 \%$ (UN, 2012). This large increase results in more demand of higher productions of food crops by the utilization of fertile lands. The developing countries are facing the threat of malnutrition. They consume the major portion of daily calorie intake from cereal crops including maize. Maize ranks $3^{\text {rd }}$ among the major cereal crops of the world (Magda pal et al., 2006). In several countries of the world, including Asia, Africa, North America and Middle East, maize is used as staple food providing a major segment of nutrients and proteins to the masses (Guzman et al., 2004). 
Maize seeds are utilized as food by the humans and the livestock. The stem is used as forage and for the production of livestock silage. Due to the great positive effects of grain in agro-based manufacturing, it becomes a important crop of commercial importance. There is in Pakistan, the maize assembly takes accelerated in the period 2009-2011 from 3262 thousand tons to 3341 thousand tons. It is $2.4 \%$ increase in annual production (GoP, 2010).

Maize plant may bear a wide range of climates ranging from tropical to subtropical climates. This is the main reason that it suits the environmental conditions of Pakistan. Maize is a source of diverse group of food and cosmetic products, which make it constantly mounting crop. Maize seed has high nutrient value with $72 \%$ carbohydrates, $10 \%$ proteins, $3 \%$ sugar and only $1.7 \%$ ash (Chaudhary, 1983). Maize hybrids have also been developed which have a promising yield potential. There is a strong room for improvement in the production technology so that the farmer may get higher production of the crop. Fertilizers should be applied in a balanced way so as to manage the nutrients' balance and for playing a role in the production enhancement. Maize crop requires a balanced application of basic nutrients such as $\mathrm{N}$, $\mathrm{P}, \mathrm{K}, \mathrm{S}$ and $\mathrm{Mg}$. Balanced application of nutrients through fertilizers is the basic for the proper growth and development of the crops. It also has the characteristics of accumulation, which is the nutrient absorption by the plants. Accumulation requires a systematic way of application on the part of mineral fertilizers which suits the maize crop. Nitrogen has a very critical role, as it determines the size of grain and the overall production of the crop.

Sulphur is not given importance as a necessary nutrient for plant growth during fertilizing the soil in Pakistan. There is very little widespread knowledge of farmers about the importance of Sulphur in plant growth. Ahmad et al., (1994) illustrated that there is less SO4-S ratio in the soils of arid areas as compared to the irrigated areas of Pakistan. In Rawalpindi $70-80 \%$ of the soils are deficient in Sulphur with less than $10 \mu \mathrm{g} \mathrm{g}^{-1}$ of soil. With the increase of Sulphur demand by the plants, there may be Sulphur deficiency in the areas where there is very less Sulphur in the rooting zone. Such soils take precise less organic matter concentration, they are unable to retain Sulphur for long. Additionally, such soils have coarse texture. Much of such soils is present in the pothohar areas of Punjab (Nizami et al., 2004).

(Griffths et al., 1995) demonstrated the provision of Sulphur to the crops has both ecological and economic significance. Due to the Sulphur deficiency, nitrogen use efficiency may be drastically decreased resulting in alteration in environment by percolating Sulphur into the soil profile. All the enzymes also are composed of Sulphur and thus they are capable of synthesizing nitrogen compounds. Bettany (1984) claimed that Sulphur is necessary for the assimilation of nitrogen in plants. Due to this reason Sulphur is used in the formulation of fertilizers. The most abundant and easily available form of Sulphur is calcium sulfates. As Sulphur is hydrophobic, the plants cannot adsorb it directly with water. It can be used by the plants after the soil bacteria convert it to soluble derivatives. Sulphur has the capability to improve the efficiency of other nutrients too, especially, nitrogen and phosphorous. The Sulphur particles produced biologically, have the potential are hydrophilic. This is due to a biopolymer coating and thus these are easily available to the plant after mixing in the soil water. The Sulphur requirement of plants is almost equal to that of phosphorous and in some cases it surpasses the phosphorous requirements. Sulphur is essential for plant development, nodules forming and immunity system. Many countries in Europe have experienced Sulphur deficiency in soils. When Sulphur is not sufficiently provided by the environment, the need for the application of Sulphur fertilizers increases.

Sulphur is found mostly in organic or inorganic form and it is unavailable to the plants. To make it available to the plants, Sulphur should be separated from the organic matter and should be mineralized. Mineralization results from microbial activities. It was observed that the supply of Sulphur to plants was low in greenhouse studies as compared to open fields ( Widdowson and Hanway, 1974; Hoeft et al., 1985; Sexton et al., 1998). In the cases where prolonged times of crop removal, leaching of sulfates, no fertilizer application and low organic manure mostly in the soil, it was observed that soil Sulphur levels were drastically decreased. The objective of this study was to check the growth and yield response of maize under $\mathrm{S}$ application and to check the concentration of $\mathrm{S}$ in maize crop.

\section{Material and method}

The experiment was was conducted in Ayube agriculture Research institute in faislabad in summer 2017 to check the behaviour of $S$ in maize crop. The experiment was laid out under RCBD with 5 level of $S$ at $0,10,20,30,40 \mathrm{~kg} / \mathrm{ha}$ in the form of gypsum. Recommended dose of NPK was applied in the form of Urea, DAP and potassium sulphate. Nitrogen was applied in two splits. Before sowing the crop the field was ploughed with two times. The seed of maize was sowed in rows by maintaining the distance between plants. The crop was harvested according to the crop demand. The crop was harvest at maturity. After harvested the crop, fresh weight, dry weight and yield of crop was recorded. Plant sample was digested with di acid $\left(\mathrm{HNO}_{3}+\mathrm{HClO}\right)$ and analysed the plant sample. Soil samples was collected from 0-15 and $15-30 \mathrm{~cm}$ depth.Different soil chemical properties was analysed. As shwon in table 1. 
Table 1. Chemical properties of the soil

\begin{tabular}{lll}
\hline properties & Soil $(\mathbf{0 - 1 5} \mathbf{~ c m})$ & soil $(\mathbf{1 5 - 3 0} \mathbf{~ c m})$ \\
\hline $\mathrm{EC}\left(\mathrm{dS} \mathrm{m}^{-1}\right)$ & 1.34 & 1.31 \\
$\mathrm{pH}$ & 7.5 & 7.70 \\
$\mathrm{O} . \mathrm{M}(\%)$ & 0.67 & 0.62 \\
Olsen $\mathrm{P}\left(\mathrm{mg} \mathrm{kg}^{-1}\right)$ & 10 & 9.9 \\
Extractable K( $\left.\mathrm{mg} \mathrm{kg}^{-1}\right)$ & 220 & 200 \\
\hline
\end{tabular}

\section{Basic soil Analysis}

The ECe $\left(\mathrm{dSm}^{-1}\right.$ is a measure of the soil salinity: 1-2 affects a few plants, 2-4 affects some plants, $>4$ affects many plants. The $\mathrm{pH}$ optimum depends upon soil organic strontium matter and clay content, for clay and loam soils under 5.2 is too acidic 6.5 to 7 is ideal and over 9 is too alkaline Phosphorus $(\mathrm{mg} / \mathrm{kg}$ soil ) $0-7$ is low $8-15$ is medium and over 15 is high. Potassium (mg/kg soil) $0-60$ is low $60-120$ is medium and 121-180 is high. Sulphate-sulphur (SO4 - -S) mostly Plants take Sulphur in the sulphate usage. Sulphate is mostly leach down where the rain fall is high and due to this factor soil test mostly not linked with plant development. But where the rain fall is less then soil test information is very useful. In the irrigation water has the more amount of Sulphate- Sulphur. Plant analysis such as N:S ratio is done usually for the Sulphur deficiency. Sulphur $(\mathrm{ppm})<2$ is Very low, 2-5 is low,5-20 medium and $>20$ is high. Sulphur recommendation (lb S/acre) for very low is 30-60, for low 10-30, for medium 0-20 and for high Sulphur content recommendation dose of Sulphur is 0 (lb /acre).

\section{Result and Discussion}

\subsection{Plant growth}

\subsubsection{Fresh weight}

Sulphur levels significantly $(\mathrm{P}<0.05)$ affected different growth parameters compared to the control. Sulphur levels increased total fresh matter significantly $(\mathrm{P}<0.05)$ compared to the control . Maximum total fresh matte $\left(26.3 \mathrm{t} \mathrm{ha}^{-1}\right)$ was produced with $\mathrm{S} 40 \mathrm{kgha}^{-1}$ soil. followed by S30 $\mathrm{kgha}^{-1}$ soil while total fresh matter $\left(19.5 \mathrm{t} \mathrm{ha}^{-1}\right)$ was recorded with control. This is might be due to the Sulphur uptake is more where Sulphur level was applied more.

\subsubsection{Dry matter}

Sulphur levels significantly $(\mathrm{P}<0.05)$ affected different growth parameters compared to the control. Sulphur levels increased total dry matter significantly $(\mathrm{P}<0.05)$ compared to the control . Maximum total dry matter $\left(19.2 \mathrm{t} \mathrm{ha}^{-1}\right)$ was produced with $\mathrm{S} 40 \mathrm{kgha}^{-1}$ soil. followed by S30 $\mathrm{kgha}^{-1}$ soil while total dry matter $\left(10.4 \mathrm{t} \mathrm{ha}^{-1}\right)$ was recorded with control. This is might be due to the Sulphur uptake is more where Sulphur level was applied more.

\subsubsection{Grain yield}

Sulphur levels significantly $(\mathrm{P}<0.05)$ affected different growth parameters compared to the control. Sulphur levels increased grain yield significantly $(\mathrm{P}<0.05)$ compared to the control . Maximum grain yield $(349.4 \mathrm{~g})$ was produced with S40 kgha ${ }^{-1}$ soil. followed by S30 kgha ${ }^{-1}$ soil while grain yield $(330 \mathrm{~g})$ was recorded with control. This is might be due to the Sulphur uptake is more where Sulphur level was applied more.

\begin{tabular}{cccc}
\hline Treatments Kg/ha & Total Fresh matter $\left(\mathbf{t ~ h a}^{-1}\right)$ & Total Dry matter $\left(\mathbf{t ~ h a} \mathbf{~}^{-1}\right)$ & $\mathbf{1 0 0 0}$ grain weight $\mathbf{( g )}$ \\
\hline 0 & $19.4 \mathrm{a}$ & $10.4 \mathrm{a}$ & $330.2 \mathrm{a}$ \\
10 & $20.4 \mathrm{~b}$ & $12.4 \mathrm{~b}$ & $331.5 \mathrm{~b}$ \\
20 & $23.5 \mathrm{c}$ & $15.7 \mathrm{c}$ & $334.5 \mathrm{c}$ \\
30 & $24.8 \mathrm{~d}$ & $16.5 \mathrm{~d}$ & $343.6 \mathrm{~d}$ \\
40 & $26.3 \mathrm{e}$ & $19.2 \mathrm{e}$ & $349.4 \mathrm{e}$ \\
LSD & 0.3 & 0.5 & 0.6 \\
\hline
\end{tabular}




\subsection{Sulphur (\% ) concentration in maize grain}

An increased concentration of Sulphur in grains was recorded by increasing S levels significantly $(\mathrm{P}<0.05)$ in normal soil compared to the control. $(0.52 \%)$ The maximum concentration of $\mathrm{S}(0.115 \%)$ in grains that was recorded with $\mathrm{S} 40 \mathrm{kgha}^{-1}$ followed by $\mathrm{K} 30 \mathrm{kgha}^{-1}(0.1063 \%)$ while minimum concentration of potassium $(0.079 \%)$ in grains was recorded with control. however, $\mathrm{S}$ concentration was higher in grains of plants grown in normal soils with increasing level of $\mathrm{S}$.

Table 2. S(\%) in maize grains

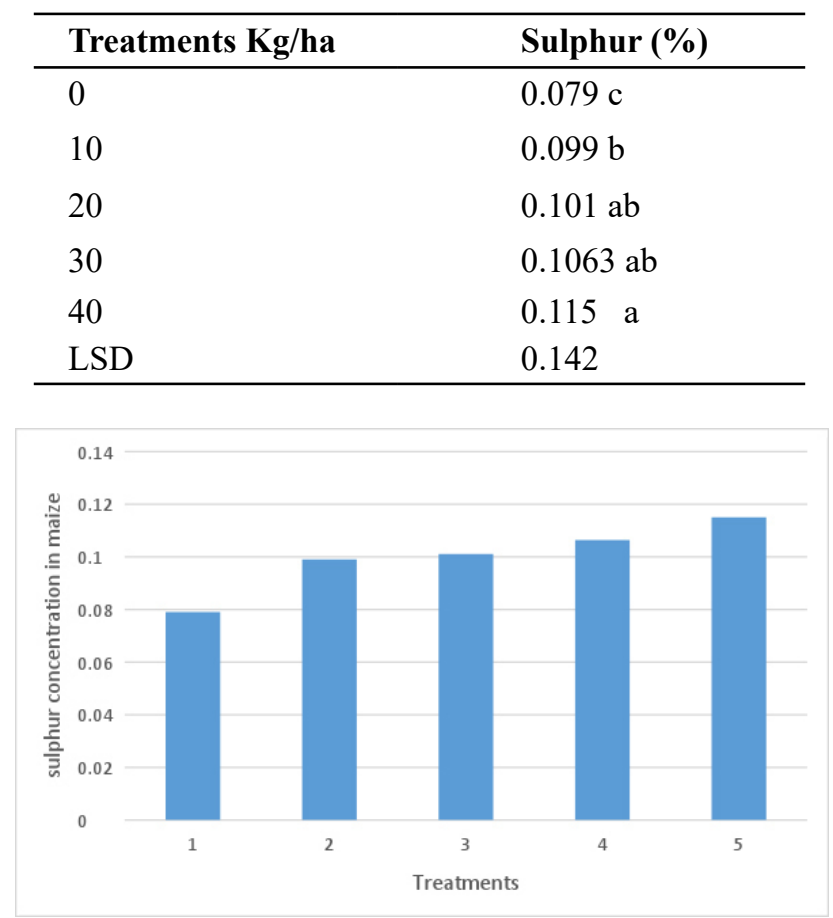

Fig.1 S Concentration in maize grain

The data regarding Sulphur concentration in maize grain is represented in Fig.1.The highest sulphur concentration $(0.115 \%)$ was observed in T5 where S containing fertilizer was applied while T1 showed the least amount of sulphur $(0.079 \%)$ because no fertilizer was applied in this treatment. Data also revealed that increase in $\mathrm{S}$ contents was gradual and directly proportional to the applied S concentration.

\section{Conclusion}

The field experiment was conducted in Soil Chemistry Research area of AARI, Faisalabad to observe the effect of Sulphur application on maize. There were 5 treatments along with 3 replication. One treatment contained Sulphur fertilizer applications. The result was statistical analyzed by using RCBD design. The data obtained from analysis shows that the concentration of Sulphur increases with the increase of Sulphur fertilizer.

\section{References}

Ahmad, A. and M. Z. Abdin. 2000. Interactive Effect of Nitrogen and Sulphur on the oil annd protein contents and on the fatty acid profiles of oil in the seeds of rapeseed (Brassica compestris L.) and mustard (Brassica juncea L. Czern and Coss). J. Agronomy and Crop Science. 183: 1-6.

Ahmad, N., M. T. Saleem, M. Rashid and A. Jalil. 1994. Sulfur Status and Crop Response in Pakistan Soils. National FertilizerDevelopment Center. Pub. No. 7/94. Planning and Dev. Div., Islamabad. pp.1-5Aulakh, M. S. 2003. Crop response to sulfur nutrition. In: Y. P. Abrol and A. Ahmad (eds.) Sulfur in Plants. Kluwer Academic PublDordrecht. PP. 341-354

Akuamoa-Boateng, A. 2002. Quality Protein Maize: Infant Feeding Trials in Ghana. Ghana health Service, Ashanti, Ghana. Ali, A. , Z. Iqbal, S. A. Hassan, M. Yaseen, T. Khaliq and S. Ahmad. 2013. Effect of nitrogen and sulphur on phenology, 
growth and yeild parameters of maize crops. Sci.Int.(Lahore). 25:363-366.

Alway, F. J. 1940. A nutrient element slighted in agricultural research. J. Am. Soc. Agron. 32:913-921.

Aulakh, M. S., N. S. Pasricha and N. S. Sahota. 1980. Yield, nutrient concentration and quality of mustard crops as influenced by Nitrogen and sulphur fertilizers. J. Agric. Sci. Camb. 94: 545-549.

Chaudhary, A. R. 1983. Agronomy. In: Maize in Pakistan. Punjab Agriculture Coordination Board, Univ. Agri, Faisalabad, Pakistan.

Cui, Y., Y. Dong, Y., H. Li and Q. Wang. 2004. Effect of Elemental Sulphur on solubility of soil heavy metals and their uptake by Maize.Environment International. 323-328.

Dunphy, E.J., and J.J. Hanway. 1972. sulphur supplying power of Iowa soils. Proc. 24th Annu. Fert. and Ag Chem. Dealers Conf. Jan 11-12, Des Moines, IA. Coop. Ext. Pub. EC-713s. Iowa State Univ., Ames, IA.

Fismes, J., P. C. Vong, A. Guckert and E. Frossardd. 2000. Influence of sulphur on apparent N-use efficiency, yield and quality of oilseed rape (Brassica napus L.) grown on a calcareous soil. Eur. J. Agron. 12: 127-141.

Ganeshamurthy, A.N. (1996) Critical plant sulphur content and effect of S application on grain and oil content of rainfed soybean in Vertic Ustochrepts. Society of Soil Science of India Journal, 44: 290-294

Govt. of Pakistan. 2008. Economic Survey of Pakistan. Pakistan Federal Beauro of Statistics. Islamabad.

Griffths M. W., P. S. Kettlewell and T. J. Hocking. 1995. Effects of foliar-applied sulphur and nitrogen on grain growth, grain sulphur and nitrogen concentrations and yield of winter wheat. Journal of Agriculture Science. 125: 331-339.

Grombacher, A. and L. Nelson. 1992. Canola Production. A Publication of Nebraska Neb Guide University. No. G921076-A.

Havlin, J. L., J. D. Beaton, S. L. Tisdale and W. L. Nelson. 2004. Soil fertility and fertilizers. An introduction to nutrient management.7th ed. Pearson Education Inc. Singapore. 221p.

Hammad, M.H., A. Ahmad, T. Khaliq, W. Farhad and M. Mubeen. 2011. Optimizing rate of nitrogen application for higher yield and quality in maize under semi arid environment. Crop \& environment. 2 (1), 38- 41.

Haneklaus, S., H. M. Paulsen, A. K. Gupta, E. Bloem and E. Schnug. 1999. Influence of Sulphur Fertilization on Yield and Quality of Oilseed Rape and Mustard. In: New Horizons for an Old Crop. Proc. $10^{\text {th }}$ Rapeseed Congr. Canberra, Australian Capital Territory (ACT), Australia.

Haq, I.U., Zuhar, D., and Karim, J. (1988) Effect of sulfur application on the yield of wheat. Sarhad Journal of Agriculture, 4 (5): 123-132.

Haq, I.U., Zuhar, D., and Hussain, M.Z. (1989) Effect of sulfur fertilization on the yield of maize Sarhad Journal of Agriculture, 5 (3): 5663.

Hoeft, R.G. 1980. Crop response to sulphur in the midwest and northeastern U.S. Sulphur Agri. 4:12-15.

Hatam, M. and G. Q. Abbasi. 1994. Oil Seed Crops. In: Crop Production.. National Book Foundation, Islamabad, Pakistan. P.329.

Janzen H. and J. Bettany. 1984. Sulphur nutrition of rapeseed: influence of fertilizer nitrogen and sulphur rates. Soil Science Society of America Journal. 48:100-107.

Jackson G. D. 2000. Effects of nitrogen and sulphur on canola yield and nutrient uptake. Agronomy Journal. 92: 644-649.

Kaya, M., Z. Kucukyumuk and I. Erdal. 2009. Effect of elemental sulphur and sulphur containing waste on nutrient concentrations and growth of bean and corn plants grown on calcarous soil. African Journal of Biotechnology. 8: 44814489.

Kacar, B. and A.V. Katkat, 2007. Sulfur in crop production: invited paper. Eur. J. Agron., 14: 81-111.

Khalil, I. A., Z. Varanini and R. Pinton. 1995. Nutritional aspects of Brassica oilseed crops. Sarhad J. Agric. 11: 513-522.

Kushwaha, A.S. and Prasad, K. (1988) Effect of sulphur to wheat cultivars. Crop Research Hisar, 15: 125-126.

Lamond, R.E., M.A. Davied and W.B. Gordon. 1997. Sulphur research in Kansas, U.S.A. Sulphur 